\title{
СРАВНИТЕЛЬНЫЙ АНАЛИЗ СОЦИАЛЬНО-ПСИХОЛОГИЧЕСКОГО ПОРТРЕТОВ МОЛОДЁЖИ ПРИГРАНИЧНЫХ РЕГИОНОВ "
}

\author{
(c) 2020 Кузавко А.С. \\ кандидат экономических наук, доцент кафедры экономики \\ Смоленский государственный университет, Россия, Смоленск \\ (с) 2020 Шевченко О.А. \\ кандидат психологических наук \\ председатель правления «Агентство интеграционных инициатив», Россия, Смоленск
}

Фактор географической близости двух государств проявляется как на уровне этнической принадлежности, так и готовности к сотрудничеству и взаимодействию на лично-бытовом и межгосударственном уровне. В статье представлен анализ социально-психологические особенностей жителей Днепро-Двинского региона (Смоленской, Витебской, Могилевской областей) методом анкетирования с закрытыми и открытыми уточняющими вопросами. Исследование проводилось для выявления специфики социально-психологических мотивов жителей, определяющих возможности и основные угрозы в становлении бизнес единицы в приграничном регионе. Результаты исследования будут полезны научным работникам и специалистам, занимающимся вопросами развития приграничных регионов, а также демографическими изменениями с учетом региональной специфики.

Ключевые слова: приграничные территории, социально-демографические особенности, межгосударственная интеграция, Днепро-Двинский регион

С момента документального закрепления намерений двух независимых государств - Российской Федерации и Республики Беларусь строить единое социально-экономическое пространство - Союзное государство - прошло более 20 лет. Обусловленное общностью и неразрывностью исторических судеб двух братских народов, основанное на принципах синергии, транспарентности и доверия сотрудничество направлено на укрепление интеграционных процессов.

В рамках изыскательского процесса предстоит методом анкетирования выявить основные черты социально-психологического портрета юношей и девушек из российско-белорусского приграничья с акцентом на изучение их ценностей, авторитетов, степени эрудированности и социальной активности. Кроме того, важно определить отношение молодежного сообщества Днепро-Двинского региона (Смоленской, Витебской, Могилевской областей) к вопросу национальной идентичности, его внешнеполитические предпочтения, лояльность к вхождению в те или иные межгосударственные объединения, политико-экономические и военные блоки.
Определить будущее Союзного государства предстоит молодому поколению, и именно от него зависит, каков будет формат российскобелорусских отношений, в каком направлении будет осуществляться развитие. В этой связи с целью изучения отношения молодых людей к процессу интеграции России и Республики Беларусь, выявления их жизненных приоритетов и характерных особенностей ментальности было проведено социологическое исследование представителей приграничных регионов.

Особый интерес представляют средства коммуникации, формирующие информационное пространство современного молодого человека. Согласно отчету «Левада-центра» «Российский медиаландшафт 2019: телевидение, пресса, Интернет и социальные сети» [1], для большинства россиян основным источником информации является телевидение (72\%), однако реже всего молодежь смотрит новости по телевизору: $42 \%$ среди россиян до 25 лет против 93\% среди людей 65 лет и старше. У молодого поколения роль главного источника информации играет не телевидение, а социальные сети.

Это подтверждают и итоги нашего опроса:

\footnotetext{
* Работа выполнена в рамках Президентского гранта № 19-1-000815 «Днепро-Двинский регион - регион возможностей»
} 
информацию о жизни города, области, своей страны и мира большая часть (80\%) молодежи Витебской, Могилевской и Смоленской областей черпает из социальных сетей. Вторым по популярности источником информации у смоленской молодежи является общение с друзьями и родственниками $-52 \%$. У витебской и могилевской молодежной аудитории - информационные и новостные интернет-ресурсы (64\% и 52\% соответственно). В пределах 30\% молодых людей получают сведения из телепередач. Меньше всего в качестве источников информации у респондентов котируются газеты и журналы.

Тематика выбора информационного контента российско-белорусской молодежью представлена на рисунке 1. Как свидетельствует распределение весов по предложенным категориям тем, юных жителей Смоленской области в информационном потоке более всего увлекают путешествия (52\%). Юноши и девушки, проживающие в Витебской области, чаще всего выбирают тему науки и техники (57\%). Заинтересованность в освоении новых знаний и технологий связана с высокой доступностью информации в новостном контенте - регулярно публикуется информация о новых изобретениях, выходе технологических новинок. Также интерес к науке может быть обусловлен желанием отвлечься от повседневных проблем или принести пользу, любознательностью или стремлением к самосовершенствованию, потребностью в признании или одобрении. Юмористический контент составляет 58\% информационного пространства молодежной аудитории Могилева. Вместе с тем, так как большую долю числа респондентов составляют студенты, то популярна тема саморазвития и образования.

В период самоопределения юношам и девушкам важно понимание и дефинизация своих жизненных приоритетов, а также ценностных ориентиров, которые, как маяк в жизненной пучине трудностей и проблем, ведут личность к желаемому результату, делая ее счастливой. Ответы на вопрос «Что для Вас является самым главным в жизни? Что Вам нужно для счастья?» (рис. 2) выявили, что слагаемыми счастья для большинства молодых людей Днепро-Двинского региона являются здоровье свое и близких; ин-

\title{
Информация по каким темам Вам интересна?
}

\author{
च Соленск, \% च Витебск, \% च Могилев, \%
}

Территориальные группы (мой город, район) Покупки Семья, дети, дом Спорт Новости о событиях в стране Здоровье Профессиональные, учебные группы Психология Юмор

Мода, стиль, красота Образование, саморазвитие Экономика, финансы, бизнес Животные Еда, рецепты Путешествия Искусство и культура Наука, техника Политика

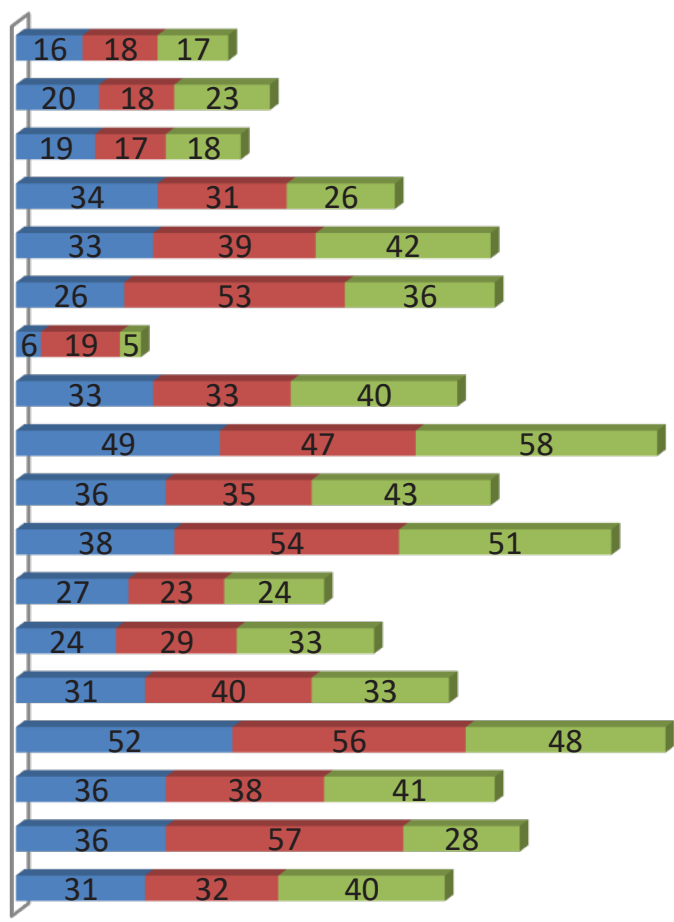

Рис. 1. Интересующие информационные темы 


\section{Что для Вас является самым главным в жизни? Что Вам нужно для счастья?}

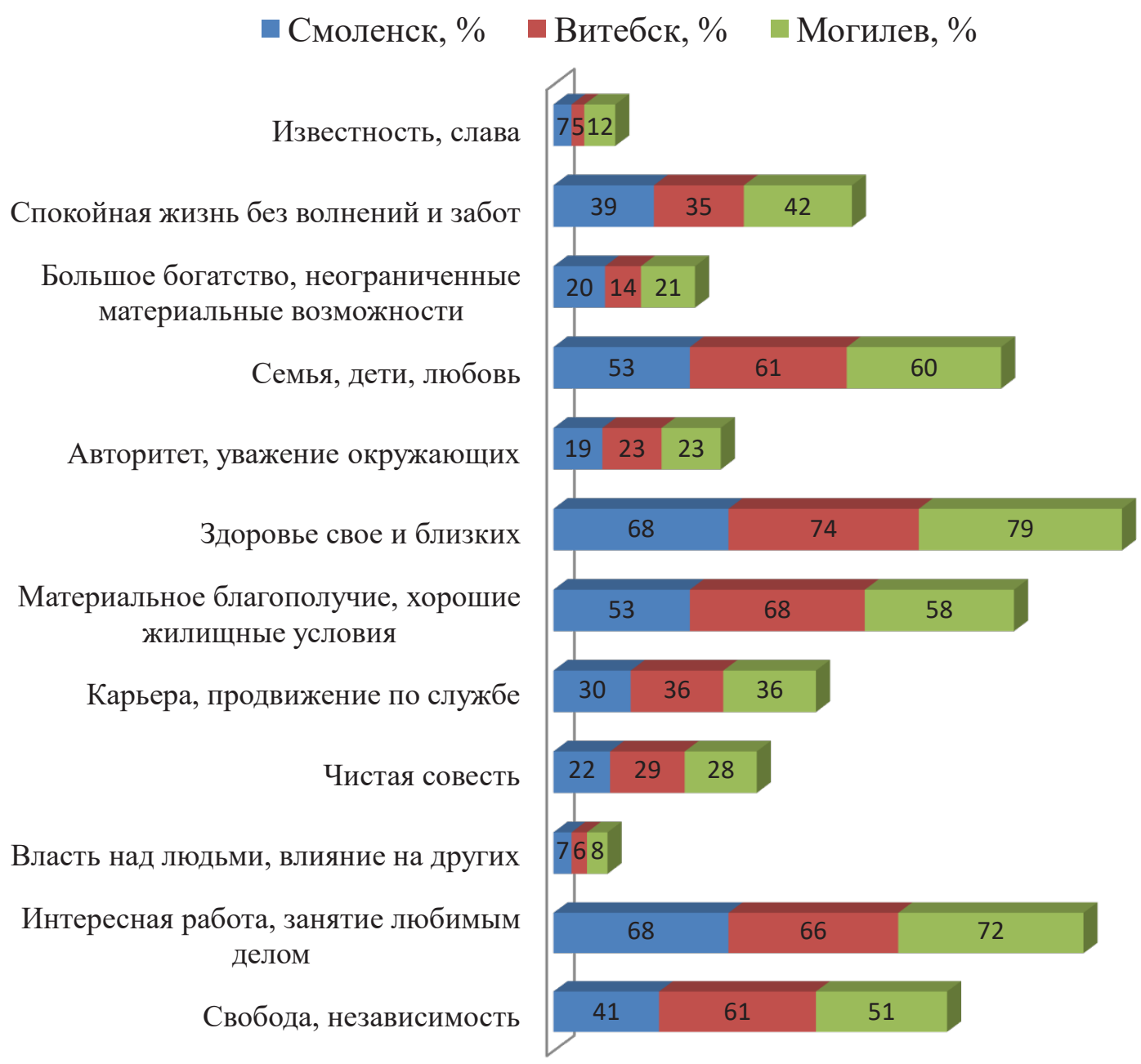

Puc. 2. Жизненные приоритеты

тересная работа, занятие любимым делом; материальное благополучие, хорошие жилищные условия, а также свобода и независимость. Менее всего их интересует власть над людьми, известность и слава. Желание славы чаще проявляется у подростков, поскольку оно произрастает из желания найти себя. Чтобы ощутить свою ценность, молодому человеку необходимо признание окружающих. Такие показатели свидетельствуют о достаточной зрелости молодых людей, участвующих в опросе, о сформированности их ценностно-ориентировочного аппарата. Низкие показатели желания власти у молодых людей приграничья свидетельствуют об их разумной самооценке и самодостаточности. Это позиция человека, который способен управлять своей жизнью, реализовывать свои способности и не впадать в зависимость от окружающих и от жизненных ситуаций.

Отвечая на вопрос «В какой отрасли хозяйства хотели бы работать после окончания вуза?», юные жители Смоленской области отдали предпочтение управленческой деятельности (37\%). Значительная часть молодых людей Витебска (80\%) и Могилева (52\%) готовы трудиться на ниве здравоохранения, просвещения, науки, культуры и юриспруденции. Профессии в сфере строительства и промышленности, торговли и обслуживания, финансов и кредитов, вооруженных сил и охраны порядка оказались менее популярными (не более 20\%). В качестве средств достижения успеха более половины респондентов отмечают способность заработать, профессию, собственность и капитал. Другая половина 
молодых людей указывает на необходимость в поддержке семьи, родственников и друзей (рис. 3). Будучи социальным существом, человеку трудно справиться с жизненными трудностями в одиночку. Потребность в поддержке означает, что у него собственного ресурса для выполнения желаемого недостаточно. Поддержка важна для совершения действий, повышающих устойчивость партнера. Когда есть тот, кто служит опорой, у партнера появляется больший диапазон маневрирования, чем был раньше.

В целом молодых людей российскобелорусского приграничья устраивает сегодняшний ход их жизни. Почти половина респондентов, проживающих на территории Смоленской, Витебской и Могилевской областей, в настоящий момент удовлетворена сложившимся жизненным укладом. Однако около 40\% юношей и девушек отмечают, что жизнь, которую они сейчас ведут, устраивает их лишь отчасти.

Возможно, это связано с темой трудоустройства молодого поколения. Отвечая на вопрос «Как Вы считаете, что мешает реализации жизненных планов молодежи в Вашем городе?», юноши и девушки Смоленска указали на невостребованность молодежи на рынке труда (43\%). 34\% смолян затрудняются ответить, где и как они могут приложить свои силы, отмечают наличие неясности перспектив предстоящего будущего. На наш взгляд, причиной этого могла стать отмена послевузовского распределения. Общая социально-экономическая ситуация в стране/регионе, по мнению молодых людей Витебска, сильнее всего препятствует самореализации. Второй проблемой они называют невостребованность на рынке труда. Это, вероятно, обусловлено переориентацией современной молодежи, отрывом от реальных потребностей государства. Также эту проблему называют и 49\% молодых жителей Могилева. Кроме того, 29\% могилевчан ссылаются на дискриминацию молодых людей со стороны старших поколений. Но почти единодушна российско-белорусская молодежь в том, что причиной нереализованных планов является менталитет современной молодежи, ее низкая активность (около 30\%).

В рамках исследования выявлены статьи расходов, формирующие потребительскую корзину молодых людей приграничья. После покупки продуктов питания и оплаты коммунальных услуг чаще всего денежные средства расходуются на приобретение одежды, обуви, аксессуаров. Около половины респондентов тратят деньги на досуг и развлечения, а также оплату мобильной связи и Интернета. Четверть проводит свой досуг, посещая кафе и рестораны. У трети опрошенных пользуются спросом покупки, связанные с индустрией красоты и здоровья, а также путешествиями. Также среди предложенных статей расходов востребованы техника и товары

\section{Что необходимо Вам, чтобы добиться успеха в жизни и чувствовать себя уверенно?}

\section{Смоленск, \% \\ Затрудняюсь ответить}

Поддержка семьи, родственников, друзей

Способность заработать. Профессия

Мой собственный оптимизм

Блат, связи

Высшее образование

Поддержка государства

Пост, должность

Собственность, капитал

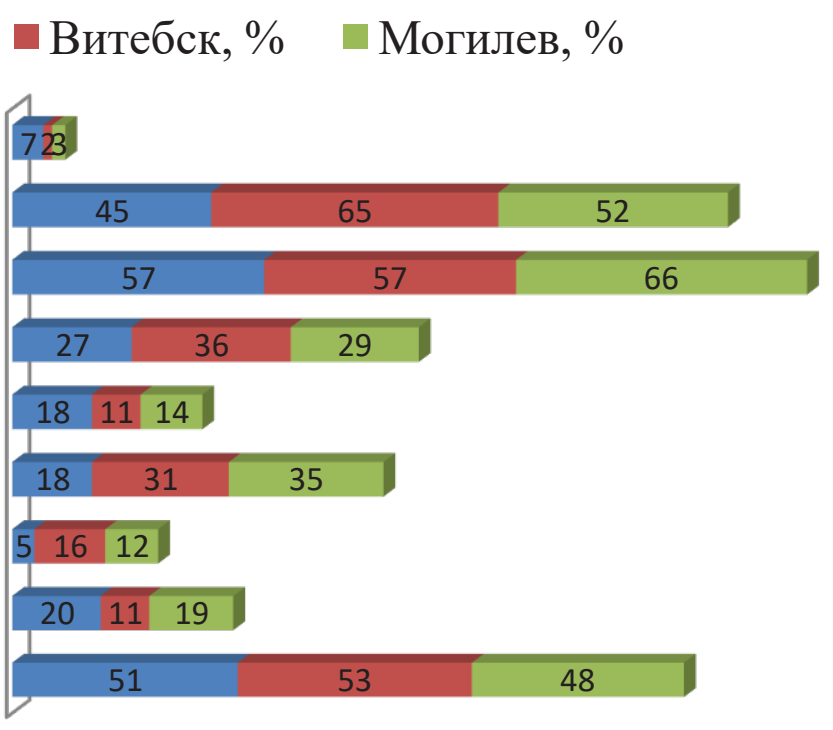

Puc. 3. Средства достижения успеха 
для дома, транспорт, сладости и снеки, спортивные товары.

Приобретать товары российско-белорусская молодежь предпочитает в гипер- и супермаркетах, в интернет-магазинах и специализированных отделах крупныхторговых центров. Четверть витебской молодежи посещает дисконт-центры. Это обусловлено приходом моды на новые форматы торговли: стандартный ассортимент, цены, выкладка товаров и оформление торговых залов. То, что еще 20 лет назад было доступно только состоятельным слоям населения, сегодня вошло в повседневность среднестатистического покупателя. Новый формат совершения покупок, предлагаемый интернет-магазинами и мобильными приложениями, прочно вошел в постоянно набирающую темп жизнь человека.

С целью определения жизненных приоритетов и потребностей молодежи Смоленска, Витебска и Могилева в одном из вопросов анкеты было предложено распорядиться гипотетически выигранным в лотерею миллионом долларов. Смоляне и витебляне чаще всего выбирали вариант вложения денег в себя, своих близких, дру- зей, в том числе оплату обучения или улучшение здоровья (46\% и 51\% соответственно). $41 \%$ и 38\% респондентов из Смоленской и Витебской областей купили бы недвижимость, машину или предметы роскоши. Треть смолян и четверть витеблян положили бы деньги в банк и жили бы на проценты (35\% и 25\% соответственно). Другая часть отправилась бы в путешествие - 24\% и $23 \%$. По 8\% смолян изъявили желание отправить выигрыш на благотворительность или вложить в развитие науки и техники. Витебляне между вариантами «отдать деньги бедным» или «вложить в развитие науки» отдали предпочтение пользе научно-технических разработок (5\% и 7\%). Большинство респондентов из Могилева потратили бы миллион долларов на приобретение недвижимости или вложения в себя или своих близких (29\% и 28\% соответственно). $12 \%$ могилевчан открыли бы вклад в банке, а 9\% - реализовали бы приз в благотворительных целях (рис. 4).

Кроме того, посредством открытых вопросов выявлено, что молодые люди приграничья при наличии стартового капитала хотели бы открыть собственный бизнес.

\section{Если бы Вы выиграли в лотерею миллион долларов, как бы Вы распорядились выигранными деньгами в первую очередь?}

Смоленск, \%

Затрудняюсь ответить

Другое

Отправился (отправилась) бы в путешествие один (одна) /с близкими

Положил(а) бы эти деньги в банк и жил(а) бы на проценты

Вложил(а) бы эти деньги в себя, своих близких, друзей (оплата обучения, здоровье)

Купил(а) бы недвижимость/машину/предметы роскоши

Вложил(а) бы эти деньги в развитие науки и техники

$$
\text { Прокутил(а) бы }
$$

Раздал(а) бы бедным или потратила бы на благотворительность

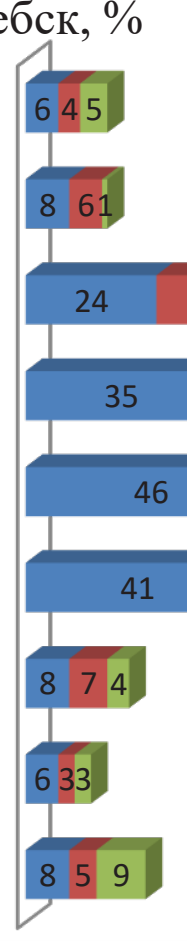

Могилев, \%

\section{8}


Отстаивать свои интересы через профсоюзную организацию готовы $7 \%$ представителей Смоленской области, 2\% - Витебской и $3 \%-$ Могилевской областей. Решить проблему путем участия в забастовках или демонстрациях предпочитают $10 \%$ смолян и $7 \%$ белорусов.

Согласно ответам на вопрос о миграционных намерениях было выявлено, что доля молодежи, желающей уехать из родного города, составила для Витебской области 51\%, для Могилевской $48 \%$ и для Смоленской $-40 \%$ от общего числа опрошенных. Достаточно высоким оказался процент лиц, затруднившихся пока дать однозначный ответ на вопрос о желании покинуть свой родной город (Витебская область - 29\%, Могилевская и Смоленская области - по 44\%). Эти данные, на наш взгляд, свидетельствуют о наличии достаточно высокого миграционного потенциала среди молодежи исследуемых областей. Почти каждый четвертый молодой человек Витебщины (23\%) и Могилевщины (23\%) планирует переехать в столицу Беларуси - Минск и почти каждый третий молодой человек Смоленщины (33\%) собирается мигрировать в столицу России - Москву. Немало желающих переехать и в другую страну. 23\% витебчан, 16\% могилевчан и $12 \%$ смолян назвали для переезда такие страны, как Германия, Польша, другие страны ЕС, а также США. Тем не менее, показатели эмиграционных намерений молодежи исследуемых областей ниже общероссийских показателей. Так, по данным опроса «Левада-центра» [2], больше половины жителей России в возрасте от 18 до 24 лет хотели бы навсегда уехать из страны. Социологи отмечают, что за десять лет этот показатель увеличился почти вдвое.

Основными причинами переезда на новое место молодые люди приграничья назвали наличие перспектив и больших возможностей реализовать себя, лучшие условия жизни и привлекательность города/страны (рис. 5).

В рамках исследования молодежи приграничья было предложено оценить социальноэкономическую обстановку своей страны и региона.

В качестве наиболее острых социальных проблем страны смоляне выбрали следующие варианты: низкий уровень жизни, заработной платы, пенсий, пособий и стипендий (63\%); преступность и коррупция (49\%); безработица

\section{Если хотите переехать, то почему, по какой причине?}

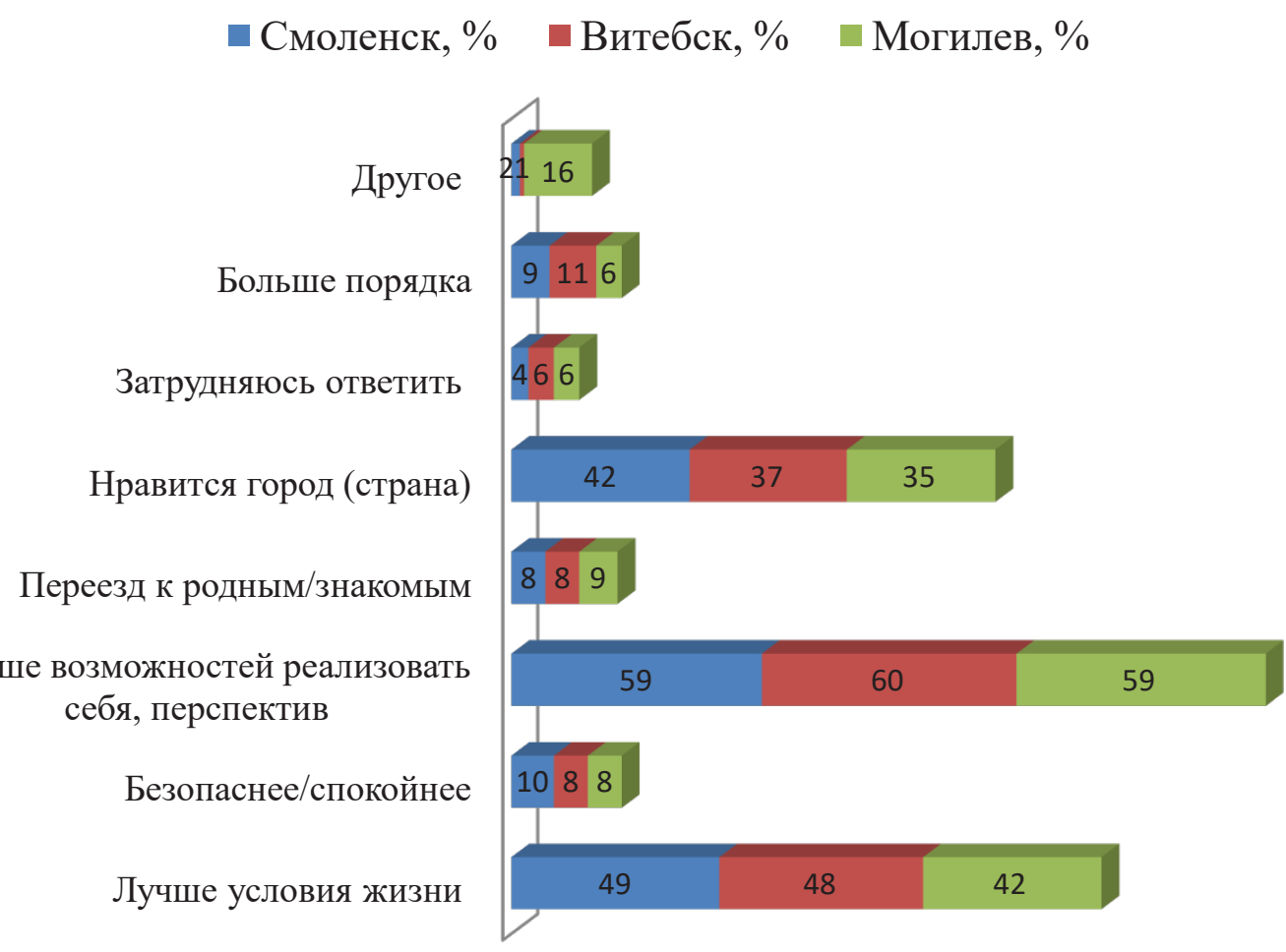

Рис. 5. Причины миграции 
и рост цен (по 43\%); низкое качество медицинского облуживания (34\%); недостаточная забота властей о населении (33\%); плохие экологические условия, загрязнение окружающей среды (30\%); пьянство, наркомания (29\%); низкий уровень демократии и высокий уровень инфляции (27\%); рост агрессии, одиночества, недоверия, недоброжелательности в обществе (26\%); низкое качество образования, рост межнациональной и социальной напряженности, проблемы ЖКХ по 21\% (таблица 1).

Белорусы основными проблемами своей страны считают низкий уровень жизни, заработной платы, пенсий, пособий, стипендий и рост цен (более половины респондентов), а также безработицу (36\% - Витебская обл., 50\% - Могилевская обл.).

В регионе проживания российская молодежь сетует на проблемы трудоустройства (43\%), низкий уровень жизни и оплаты труда (41\%), низкое качество медицинского обслуживания (31\%), проблемы жилищно-коммунального хозяйства (26\%), низкое качество образования и недостаточную заботу местных властей о жителях региона (по 20\%).

Белорусские сверстники в определении социальных проблем своего региона солидарны с россиянами. Они также в качестве остросоциальной проблемы называют низкий уровень жизни (57\% - Витебская обл., 36\% - Могилевская обл.).

Безоговорочно выразили готовность к участию в волонтерской работе, развитию спорта и пропагандированию здорового образа жизни $27 \%$ молодых людей из Смоленской области и $29 \%$ - из Витебской области. Представители Могилевской области в отличие от своих сверстников оказались более инициативными: готовы стать волонтерами 40\%, развивать спорт - 35\%, заниматься досугом детей и подростков $-32 \%$.

В случае наличия свободного времени около половины россиян и белорусов готовы активно включаться в общественную политическую жизнь, принимать участие в мероприятиях и акциях, в том числе экологических; заниматься волонтерской работой и благоустройством территорий.

Другая половина опрошенных не испытывает желания включаться в такую творческую деятельность, как написание проектов для конкурсов или участие в организации мероприятий.

Современное социально-информационное пространство меняет ментальность молодежи приграничья: обнаружен тренд к уважению трудолюбивых людей, создавших свой бизнес. Об этом свидетельствуют ответы юных представителей исследуемых областей, которые чаще всего в качестве кумира или авторитета в эконо-

Таблица 1. Социальные проблемы, характерные для региона/страны

\begin{tabular}{|c|c|c|c|c|c|c|}
\hline \multirow{2}{*}{ Социальные проблемы } & \multicolumn{3}{|c|}{ Для страны, \% } & \multicolumn{3}{|c|}{ Для региона, \% } \\
\hline & $\mathrm{C}$ & B & M & $\mathrm{C}$ & $\mathrm{B}$ & M \\
\hline Безработица & 43 & 36 & 50 & 43 & 39 & 23 \\
\hline $\begin{array}{l}\text { Низкий уровень жизни, заработной платы, пенсий, пособий, } \\
\text { стипендий }\end{array}$ & 63 & 64 & 68 & 41 & 57 & 36 \\
\hline Рост цен & 43 & 54 & 53 & 14 & 31 & 25 \\
\hline Низкое качество медицинского обслуживания & 34 & 14 & 14 & 31 & 2 & 16 \\
\hline Пьянство, наркомания & 29 & 20 & 15 & 17 & 13 & 10 \\
\hline Преступность, коррупция & 49 & 16 & 13 & 12 & 10 & 7 \\
\hline Недостаточная забота властей о населении & 33 & 19 & 11 & 20 & 14 & 10 \\
\hline Низкий уровень демократии & 27 & 13 & 9 & 9 & 7 & 3 \\
\hline Низкое качество образования & 21 & 7 & 4 & 20 & 5 & 3 \\
\hline Рост межнациональной и социальной напряженности & 21 & 3 & 2 & 8 & 2 & 4 \\
\hline $\begin{array}{l}\text { Рост агрессии, одиночества, недоверия, недоброжелательности } \\
\text { в обществе }\end{array}$ & 26 & 10 & 6 & 14 & 9 & 7 \\
\hline Плохие экологические условия, загрязнение окружающей среды & 30 & 7 & 8 & 15 & 8 & 8 \\
\hline Проблемы ЖКХ & 21 & 10 & 5 & 26 & 11 & 6 \\
\hline Высокий уровень инфляции & 27 & 7 & 5 & 7 & 4 & 3 \\
\hline
\end{tabular}


мической сфере упоминали следующие имена: Билл Гейтс, Стив Джобс и Илон Маск. Помимо прочих выдающихся личностей юноши и девушки Витебска назвали Павла Дурова, а Могилева Марка Цукерберга. Это пример людей, которые путем упорного труда и горячей любви к своему делу добились невероятных высот и мировой известности. В научной сфере в качестве авторитетных персон, с точки зрения молодежи приграничья, выявлены Стивен Хокинг и Илон Маск. В Витебской области по частоте упоминаний также лидирует имя - Никола Тесла, а в Могилевской - Игорь Александрович Марзалюк. В качестве деятелей в области молодежной политики названы Илон Маск и Алексей Навальный. Также витебляне в ряде деятелей молодежной политики отметили лидеров российского и белорусского государств В.В.Путина и А.Г.Лукашенко, могилевчане вспомнили российского журналиста и видеоблогера Юрия Дудя.

Подводя итог вышеизложенному, следует отметить, что исследованием выявлен ряд трендов, характеризующих ментальные черты современного молодого человека, проживающего на территории Днепро-Двинского региона.

Во-первых, при решении задачи по исследованию отдельных характеристик социальнопсихологического портрета юных жителей российско-белорусского приграничья выявлено, что это люди с достаточно сформированными ценностями, стремящиеся к самоопределению и саморазвитию, пребывающие в поиске себя и своей ниши в обществе. Основными ценностными ориентациями молодежи являются: здоровье свое и близких, интересная работа и занятие любимым делом, материальное благополучие, комфортные жилищные условия, свобода и независимость. Вместе с этим лейтмотивом в ряде ответов прослеживается значимость семейных и дружеских ценностей.

Стремлением к саморазвитию и поиску возможностей реализовать себя обусловлен высокий миграционный потенциал, выявленный почти у половины респондентов в каждой из исследуемых областей - Смоленской, Витебской и Могилевской. Точками притяжения стали как крупные города своего государства, так и другие страны (Германия, Польша, страны ЕС, США).

Во-вторых, медиапространство, окружающее современного молодого человека приграничья, претерпело значительные изменения. Основные инфомейкеры переместились в пло- скость интернет-ресурсов: социальные сети и информационные новостные порталы.

Обнаружена тенденция влияния медийного информационного поля, в котором фигурируют истории успешных и трудолюбивых людей, создавших свой бизнес, на формирование мотивационной сферы личности. Среди авторитетных персон в экономической деятельности выявлены американские предприниматели Билл Гейтс, Стив Джобс и Илон Маск, в научной - Стивен Хокинг, в политической - В.Путин, А. Лукашенко, В.Зеленский.

B-третьих, при оценке удовлетворенности жизнью, которую молодежь ведет в настоящий момент, прослеживается ряд социальных проблем: трудоустройство, препятствие самореализации ввиду отрыва желаемого от реальных потребностей государства, дискриминация молодых людей со стороны старшего поколения. Однако уровень удовлетворенности достаточно высокий. Интересно то, что причинами нереализованности планов современная молодежь называет менталитет и свою низкую активность.

B-четвертых, в рамках исследования изучена потребительская корзина молодежного сообщества приграничных регионов. Помимо товаров первой необходимости, молодые люди предпочитают приобретать одежду, обувь и аксессуары. Немного реже денежные средства расходуются на досуг, посещение кафе/ресторанов.

В ситуации получения крупного денежного выигрыша и дальнейшего распоряжения им у представителей трех областей наиболее популярными стали варианты приобретения недвижимости или создания собственного бизнеса, оплаты обучения или оздоровительных услуг для себя/близких.

B-пятых, при оценке социально-экономической обстановки своей страны россияне и белорусы солидарны в обозначении следующих проблем: низкий уровень жизни, заработной платы, пенсий, пособий и стипендий, а также рост цен, безработица.

В регионах проживания, помимо прочих трудностей, названы: сложности с трудоустройством, низкое качество медицинского обслуживания и образования, проблемы в сфере жилищно-коммунального хозяйства, недостаточная забота местных властей о горожанах.

При всем понимании социальнополитических проблем своей страны и региона молодые люди приграничья не проявляют вы- 
сокой социальной активности, ограничиваются лишь чтением новостей о жизни своего региона, страны, мира на информационных порталах в Интернете, обменом мнений по актуальным темам с друзьями и знакомыми, просмотром новостей по телевизору.

Недостаточная удовлетворенность молодежной политикой своей страны и мнение, что государство могло бы делать больше для молодого поколения, являются основной причиной отсутствия интереса к деятельности политических партий, молодежных движений или профсоюзных организаций. Юные жители российскобелорусского приграничья в решении своих проблем или достижении целей не замечают реальной поддержки со стороны молодежных организаций, действующих на территории их страны или региона, считают их работу формальной. Как следствие, выявлена низкая готовность к присоединению к какой-либо политической партии или молодежному движению.

В-шестых, в ходе определения ментальных скреп российской и белорусской молодежи проявляются следующие критерии сходства: общее славянское происхождение, история, совместные испытания и победы, культура и язык.

Почти треть респондентов в каждом исследуемом регионе однозначно считают, что русские и белорусы ничем не отличаются. В целом молодое поколение двух братских народов относит себя к единой этнической группе. По ряду ответов прослеживается, что русские априори не отделяют Беларусь от России.

В качестве отличительных аспектов в Витебской области названа разница в психологии, в Могилевской области - культура и традиции, в Смоленской области - язык.

В-седьмых, в эмоциональной окраске, которую чаще всего молодые люди обеих стран испытывают в отношении сопредельного государства, с российской стороны больше положительных оценок, в частности превалирует уважение. В менталитете белорусских респондентов наблюдается ряд негативных коннотаций в отношении России: разочарование и недоверие. Данный экспансивный фон связан с периодически возникающими «нефтегазовыми» и «молочными» конфликтами между странами, а также информационными кампаниями, сопровождающими их. Смоляне более лояльны в данной грани взаимоотношений, так как данные проблемы для россиян менее релевантные.

На бытовом уровне проявляется высокая степень лояльности среди молодежи приграничья. Девушки и юноши готовы с соседями породниться, создать семью, вместе трудиться, проживать рядом.

Одной из главных задач исследования стало выявление отношения российско-белорусской молодежи к процессам интеграции России и Республики Беларусь.

Несмотря на в целом положительное отношение к россиянам, белорусская молодежь настроена скорее против объединения двух стран, в то время как смоленские респонденты - скорее за. К процессу интеграции в противовес лояльности россиян белорусы относятся отчасти настороженно.

Непонимание смысла объединения Смоленской, Витебской, Могилевской областей - основной аргумент противников интеграции.

Наиболее оптимальным форматом взаимодействия двух приграничных государств, по мнению респондентов, является «независимое существование двух стран с теплыми и дружескими взаимоотношениями».

Таким образом, мы имеем в определенной мере разнонаправленные тенденции в менталитете. С одной стороны, достаточно высокую готовность к сотрудничеству на лично-бытовом уровне, с другой - дефицит доверия в межгосударственных отношениях.

Фактором близости является как этническая принадлежность, так и готовность к взаимодействию на лично-бытовом и межгосударственном уровне. В то же время все ярче проявляются точки разлома: снижение доверия, взаимопонимания, а также наличие отрицательных оттенков в русско-белорусской палитре взаимоотношений, связанных с внешнеэкономическими разногласиями и информационными кампаниями.

Для дальнейшего развития, по мнению представителей Днепро-Двинского региона, двум странам не хватает главным образом доверия и взаимопонимания.

Работа выполнена в рамках Президентского гранта № 19-1-000815 «ДнепроДвинский регион - регион возможностей» 


\section{Библиографический список}

1. Российский медиаландшафт 2019: телевидение, пресса, интернет и социальные сети // Отчет «Левадацентр» [Электронный ресурс].- Режим доступа: https:/www.levada.ru/2019/08/01/21088/, свободный.(дата обращения: 01.12.2020).

2. «Левада-центр»: 53\% молодых россиян хотят уехать из страны // Ведомости [Электронный ресурс].- Режим доступа: https://www.vedomosti.ru/politics/news/2019/11/26/817166-53-rossiyan-let-hoteli-bi-uehat-iz-strani, свободный. - (дата обращения: 01.12.2020). 